\title{
Non-industrial private forest owner's willingness-to-harvest: how higher timber prices influence woody biomass supply
}

\begin{abstract}
:
Given the large proportion of many forested landbases comprised of non-industrial private owners, there is a great need to characterize their willingness-to-harvest (WTH) bioenergy feedstocks. A choice-based study examined non-industrial private forest landowners' WTH: timber products and woody biomass, timber products only, woody biomass only, and none. A Bayesian multinomial model analyzed the impacts of timber and woody biomass prices and other explanatory variables on WTH. Landowners' demographic profile, parcel size, attitudes toward biomass harvesting and forest ownership objectives had significant effects on stated WTH. Timber revenues had a greater marginal effect on WTH of timber and woody biomass, compared with harvesting timber only highlighting the importance of strong traditional timber markets to enhance bioenergy feedstock availability. Public policy efforts aimed at increasing woody biomass supply from NIPFs might be most effective by targeting timber rather than woody biomass revenues.
\end{abstract}

Keywords: Willingness-to-harvest, Non-industrial private forest owners, Timber, Woody biomass 


\section{Introduction}

Non-industrial private forests (NIPFs) are central to the supply of raw materials to the wood products industry. In the U.S., there are about 115 million hectares of NIPFs representing about $37.9 \%$ of all forested land in the country [1]. NIPFs' role in supplying wood is magnified when focusing on particular regions of the country. For instance, in the U.S. Northern region (defined as the quadrant delimited by Maine, Maryland, Minnesota and Missouri) NIPFs account for 57.9\% of the total forested area in the region and the majority (73.4\%) of privately-owned forests $[2,3$, 4].

Given the large forest landbase proportion comprised by NIPFs, raw material supply from these ownerships will be instrumental to the development of emerging wood product markets. In recent years, partly driven by public interests in national energy independence and rising fossil fuel prices, there has been a growing interest in generating energy from woody materials [5, 6]. These materials, commonly referred to as woody biomass, include small-diameter trees $(<13 \mathrm{~cm})$ as well as portions of trees (tree limbs, tree tops, needles, leaves) and wood waste not useable in the traditional wood products industry [7]. The U.S. Department of Energy in its "Billion-ton Biomass Report" highlights the role that woody biomass will play in the U.S. to accomplish cellulosic fuel targets [8]. Already, energy derived from woody biomass accounts for one of the greatest shares $(24 \%)$ of renewable energy in the country and industrial outlooks foresee a greater demand for this renewable feedstock [9]. In addition to expanding and diversifying the U.S. energy portfolio, wood energy projects will likely be part of a comprehensive strategy to cope with the loss of manufacturing capacity of traditional wood industries [10]. A critical piece 
of information to guide the development and expansion of these projects is the true availability of forest-based biomass feedstocks within a given region.

The majority of efforts to quantify the regional availability of forest-based woody biomass feedstocks in the U.S. have focused primarily on biophysical availability by examining the quantity, quality and composition of forest resources [11]. However, given the importance of economic and social factors in influencing landowners' willingness-to-harvest (WTH) forests and supply woody biomass $[11,12]$, biophysical estimates only partially determine biomass supply from NIPFs [11]. Availability of woody biomass may be greatly decreased once economic (e.g. timber and biomass market prices) and social factors are considered. For example, forest-based biomass supply in Massachusetts may be limited to as little as $10 \%$ of biophysical estimates once social constraints are taken into consideration [13]. In Missouri, about $32 \%$ of NIPF owners might be willing to harvest woody biomass from their forests if offered an acceptable price; and net revenues higher than currently observed in the market could increase WTH by about $15 \%[11,12,14]$.

This study explored NIPF owner's WTH traditional commercial timber products (defined as timber and pulpwood) and woody biomass, the latter to be specifically used in bioenergy generation. Since markets for woody biomass as an energy source are non-existent or are in their early developmental stages, this study used an experimental approach to explore NIPF landowners' stated commercial timber and woody biomass harvesting preferences with the following specific objectives: (a) to examine factors that influence NIPF owners' WTH timber and woody biomass; and (b) to predict NIPF owners' stated commercial timber and woody 
biomass harvesting probabilities under different market scenarios (i.e. varying timber and woody biomass revenues). Empirically, this study focused on three states within the U.S. Northern Region: Michigan, Minnesota and Wisconsin. These states were selected due to their projected importance as sources of woody biomass [15], the predominance of NIPFs, and the presence of dynamic commercial timber markets $[1,4]$ required for the economies of scale necessary to procure woody biomass materials in a cost-effective fashion $[9,16]$.

This manuscript is organized as follows. Section 2 reviews previous WTH woody biomass studies and outlines the unique contributions of this research. Section 3 defines our theoretical framework. Section 4 describes the experimental approach and describes the methods applied to collect and analyze our data. Section 5 presents descriptive statistics, the results from analytical models and predictions for NIPF owners' harvesting preferences under selected market scenarios. We conclude stressing the importance of our results within the context of feedstock availability estimates and bioenergy policy and outlining needs for future research.

\section{Literature review}

NIPF owners' commercial harvesting behavior for timber and pulpwood has been discussed extensively in the literature $[17,18,19]$. NIPF owners' harvesting preferences are complex partly due to the fact that forests in the U.S. are owned for multiple objectives - often dominated by non-commercial reasons such as privacy, recreational and bequeathing opportunities [3, 19, 20]. The literature stresses the importance of examining ownership objectives when exploring NIPF harvesting preferences and identifies their influential effects on commercial harvesting behavior $[17,21,22,23]$. The perceived association between harvesting and environmental degradation 
has been reported as a factor potentially limiting timber supply from NIPFs particularly among those with strong bequeathing and environmental conservation objectives [14, 23, 24]. Besides ownership objectives, the literature identified other factors as being influential to NIPF owners' timber and pulpwood harvesting preferences. The most frequently discussed factors include timber market prices [17, 25, 26], landowners' parcel size [3, 27, 28, 29], on-site or absentee ownership [3, 28], and demographic profile [21, 28, 30].

Another more recent stream of the literature has identified factors that may affect NIPF owners' WTH woody biomass in the U.S. [13, 31, 32, 33, 34]. Becker et al. [32] surveyed Minnesota family forest owners and identified woody biomass price, landowners' perceptions and attitudes toward woody biomass harvesting to be statistically influential to landowners' stated woody biomass harvesting preferences. Markowski-Lindsay et al. [13] studied Massachusetts NIPF landowners' WTH woody biomass and found that harvesting preferences were mainly affected by woody biomass price but the size of forest ownership had no statistically significant effect on stated woody biomass harvesting preferences. However, Joshi and Mehmood [33] surveyed private forest owners in Arkansas, Florida and Virginia, and found a positive correlation between forest ownership size and WTH woody biomass. Statistically significant effects of forest ownership size on WTH woody biomass have also been reported in Mississippi [35]. The apparent inconsistency of forest size impacts on biomass harvesting preferences may be explained by different study areas and sample selection methods. For example, Joshi and Mehmood [33] only surveyed owners of at least 8 ha of forests, Gruchy et al. [35] participants owned at least of at least 100 ha, while Markowski-Lindsay et al. placed no minimum forest size ownership condition in their sample [13]. Excluding owners of smaller forest sizes can diminish 
discernable size effects on WTH since landowners of smaller-sized ownerships (e.g. <4 ha) are less likely to engage in forest management [3].

However, the same literature exploring NIPF owners' WTH woody biomass seldom discusses commercial timber harvesting preferences. Previous forest operation studies have identified the harvesting of woody biomass jointly with timber and/or pulpwood products in order for it to be an economically feasible endeavor $[36,37]$. Hence, it seems incomplete to explore landowners' WTH woody biomass without also examining their commercial timber harvesting preferences, particularly given that integrated harvests (commercial timber harvests in which woody biomass is also harvested) are the primary means by which woody biomass is procured [38]. This study differs from the present literature in that we aim to fill this shortcoming. To achieve this, we developed an experiment to elicit NIPF owners' WTH for four potential harvesting scenarios: (1) integrated harvesting of commercial timber products and woody biomass, (2) traditional harvesting of commercial timber products only, (3) woody biomass harvesting only, and (4) none. Specifically, we focused on examining and interpreting factors that may affect NIPF owners' preferences for conducting an integrated harvest over traditional harvesting (e.g. only timber removals) or not harvesting at all.

\section{Theoretical framework}

This study used a random utility framework to capture the effects of economic, environmental and social factors on NIPF owners' WTH. A NIPF owner (i) derives benefits (i.e. utility) from forest harvesting. This utility $(U)$ varies across a choice $j$ from a set of potential harvesting scenarios $J$ ( $j=1$ : timber and woody biomass harvest; $j=2$ : timber harvest only; $j=3$ : woody 
biomass harvest only; $j=4$ : not to harvest). In our model, a NIPF owner's utility for a particular harvest choice $\left(U_{i j}\right)$ is composed of a deterministic component $\left(V_{i j}\right)$ and a random error term $\left(\varepsilon_{i j}\right)$ $[39,40]:$

$$
U_{i j}=V_{i j}+\varepsilon_{i j}=F(M, L, O)+\varepsilon_{i j},
$$

where $V_{i j}$ is a function of market $(M)$, forest land $(L)$ and owner characteristics $(O)[18,19,32$, 41]. Market information captures market revenues from sales of timber and/or woody biomass. Forest land characteristics include volume of commercial timber in the county where an ownership exists, and size of forest ownership. Landowner characteristics include attitudinal, perceptual and socio-economic conditions as these are particularly important when studying hypothetical market scenarios [42]. Specifically, we included NIPF owners' attitudes associated with the environmental impacts of woody biomass harvesting, motivations for managing forestlands and demographic information (income, age, education and gender) reported to be influential of WTH in the literature. Rational NIPF owners choose the harvesting scenario that maximizes their utility [17, 43], for instance, harvesting scenario $j$ will be selected if $U_{i j}>U_{i k}(\forall k$ $\neq j)$.

Empirically, market data were derived from revenues from selling commercial timber and/or woody biomass using USDA Forest Service Inventory and Analysis (FIA) data and publicly available product price reports. Forest land and owner characteristics were collected by surveying NIPF owners in Michigan, Minnesota and Wisconsin and also derived from FIA data. Parameterization of market, land and owner characteristics effects on NIPF owners' WTH was conducted using Bayesian multinomial logit regression models described next. 


\section{Methods}

This section describes data collection, which included the development of a survey and subsequent mailing, and analytical methods. The survey used to gather data from NIPF owners is described first. It included the definitions associated with woody biomass, traditional commercial timber harvest, and integrated commercial harvest, description of the four hypothetical market scenarios used to explore harvesting preferences, and survey questions designed to gather land and demographic characteristics. We then outline the process of sample selection and survey distribution. This section concludes with a description of our econometric analysis, including a discussion of the rationale for using a Bayesian approach, variables included in our models, and information associated with the implementation of Bayesian multinomial logit regression models.

\subsection{Survey instrument}

A mail survey was chosen as the most effective and cost-efficient way to reach NIPF owners in the region. A survey instrument was developed following the Tailored Design Method [44]. It followed the general structure developed by Daniel [45] where a definition of woody biomass adapted from the USDA Forest Service [7] was provided to the respondents at the beginning of the questionnaire. The feasibility of utilizing woody biomass to generate different types of bioenergy was also explained to reduce knowledge differences associated with bioenergy production using woody biomass [46].

Definitions of traditional commercial timber harvest, and integrated commercial harvest for timber and woody biomass were provided as follows: "Commercial timber harvest includes removal of trees at least 5 inches $(12.7 \mathrm{~cm})$ in diameter for sawlogs that are used for making 
solid wood products and pulpwood used by the pulp and paper industry", and "integrated commercial timber and woody biomass harvest includes the removals of sawlogs and pulpwood for traditional products and woody biomass for energy use". Pictures illustrating a representative forest in the area after traditional timber harvesting, integrated timber and woody biomass harvesting, and woody biomass harvesting only were also included in the survey.

Following these definitions that helped frame the choice-based WTH experiment, the questionnaire presented hypothetical market scenarios. Under each scenario, respondents were asked their most preferred harvest choice for a representative forest under certain timber and woody biomass revenues (see Appendix A for calculations of harvest volumes). The representative forest described average product volumes per acre in a commercial harvest based on FIA data for counties included in the study area [47]. The scenario was presented such that respondents were first asked to state their harvest choice given a per-acre revenue from the harvest of timber and pulpwood followed by their preferred choice given potential revenues peracre from harvesting woody biomass. Our questionnaire design followed this order because for current forest management in the region it is only economically feasible to harvest biomass after timber harvesting.

Commercial prices used for the hypothetical market scenarios were set differently across states based on current pulpwood and sawtimber markets [48, 49, 50]. Average commercial timber revenues were estimated to be $\$ 1012.7 / \mathrm{ha}$ (\$410/acre) in Michigan, $\$ 1111.5 / \mathrm{ha}$ ( $\$ 450 /$ acre) in Minnesota, and \$1333.8/ha (\$540/acre) in Wisconsin (Please see Appendix B for revenue 
estimation based on individual product prices). To capture the revenue effects on NIPF owners' WTH, a total of four price levels were generated for each state.

Revenue levels from woody biomass harvesting were set based on observed bioenergy markets in Minnesota. Due to lack of public information for woody biomass prices at the time of the study, Minnesota's average biomass prices were determined through personal communications with wood product market experts from the Minnesota Department of Natural Resources. In 2010, Minnesota's average bio-stumpage value for logging slash from all ownerships was $\$ 1.50$ per green short-ton (gt) and ranged from $\$ 1$ to $\$ 2$ per gt (Donald Deckard, pers. comm., Aug. 17, 2011). Based on feedback from the Michigan and Wisconsin Departments of Natural Resources, it was determined that the same rates could also be applied in the Michigan and Wisconsin's versions of the survey. Four biomass price offers were developed, which were set at $\$ 0 / \mathrm{gt}$, $\$ 1 / \mathrm{gt}$, $\$ 2 / g t$ and \$3/gt to capture biomass price effects on landowners' WTH woody biomass. Based on calculations for biomass volumes per acre (around 20gt/acre or 49.40gt/ha for three states) presented in Appendix A, we included biomass revenues in the questionnaire as: $\$ 0 / \mathrm{ha}$ ( $\$ 0 / \mathrm{acre}$ ), $\$ 49.42 / \mathrm{ha}$ (\$20/acre), \$98.84/ha (\$40/acre), \$148.26/ha (\$60/acre).

\section{<Insert Table 1 About Here>}

In addition to stated WTH, the survey gathered information about NIPF owners' land characteristics including total forest ownership (in acres), and whether or not their primary residence sits on their forests. Forest owners were also asked about past timber harvesting and selling experience, whether they have a management plan written by a professional forester or 
not, as these are known to influence future harvesting preferences [21, 51]. Attitudes regarding bioenergy support and perceived environmental impacts, that have been identified as latent factors behind NIPF owners' WTH [14], were obtained by asking participants for levels of agreement to the statements "I support harvesting woody biomass for energy" and "Harvesting woody biomass is likely to result in soil erosion" using five-point Likert scales (1= Strongly disagree, $3=$ Neither agree nor disagree, 5= Strongly agree). Another land characteristic included in this study was the average commercial timber volume per acre in the county where landowners' forests were located. These volumes, obtained from the FIA database, were deemed to reflect on the development of local wood product markets and quality of timber stands.

NIPF owners' motivations for managing their forestlands were also collected in the questionnaire. Respondents' levels of agreement to several statements adapted from the National Woodland Owner Survey were asked [52]. These were: "To enjoy beauty or scenery", "For production of sawlogs, pulpwood or other timber products" and "As a part of my inheritance". A five-point rating scale ( $1=$ Not important; $3=$ Moderately important; 5=Extremely important) was used to measure landowners' responses to these statements. Respondents' demographic information (age, gender, gross annual household income) was collected in the last section of the survey.

The survey was mailed to a random sample of NIPF owners with at least 8.09 ha (20 acres) of ownership in Michigan, Minnesota and Wisconsin in areas where timber is commercially traded. The acreage screening was set as this ownership group is the most likely to conduct a commercial harvest [53]. Also, we focused on counties with higher levels of woody biomass feedstock not only because they may contribute greatly to biomass production, but also because 
bioenergy projects are more likely to be located in places where there is higher woody biomass availability $[15,54]$. A database of landowners' names, addresses and acres owned was created from county tax assessors and online parcel maps. Pretest surveys were mailed to 48 respondents in the three states to ensure the accuracy and interpretability of the overall questionnaire. After pretest, surveys were mailed in March and April, 2012, reminder postcards and full surveys were mailed to landowners again two weeks later to increase participation rate [42].

\subsection{Econometric analysis}

Data analysis was conducted using multinomial logit regression models based on a Bayesian framework. Two econometric models with the same dependent variable (NIPF owners' harvesting choice) were developed. Model 1 (reduced model) only included revenue variables to capture market effects on WTH levels of an average respondent. Model 2 (full model) also controlled for forestland and landowner characteristics.

A Bayesian analysis was selected because of its ability to incorporate prior information into the analysis [55]. This approach allowed us to integrate findings from previous research on factors influencing NIPF owner's WTH to more accurately estimate the likelihood of harvesting. Compared to a non-Bayesian approach where regression $\beta$ coefficients are solely estimated based on a given sample, Bayesian analysis allows the introduction of prior information in the estimation of parameters from a dataset to generate a posterior distribution (i.e. data + prior information) of model parameters, which could be represented as [56]:

$\operatorname{Prob}(\beta \mid$ data $) \propto \operatorname{Prob}($ data $\mid \beta) \operatorname{Prob}(\beta)$ 
where $\operatorname{Prob}(\beta \mid$ data) is the posterior probability, which quantifies the probability of the parameters $\beta$ given our data, $\operatorname{Prob}(\beta)$ is the prior distribution, which indicates the probability of the parameters $\beta$ before our data is observed. $\mathrm{P}(\operatorname{data} \mid \beta)$ is the likelihood function for the multinomial logit model, which could be represented as in Equation 3 [57]:

$$
\ln L\left(\operatorname{data} \mid \beta_{j}\right)=\sum_{i=1}^{N} \sum_{j=1}^{J} Z_{i j} \ln \operatorname{Prob}\left(y_{i}=j\right)
$$

where $Z_{i j}$ was equal to 1 when choice $j$ was selected and 0 otherwise. $N$ is the total number of observations. Parameters that have values generating the largest likelihood are the most supported by the data. According to Bayesian theorem $[56,58]$, the posterior distribution can be calculated by multiplying the likelihood function and prior distribution, which is given by:

Posterior $\propto \ln L\left(\right.$ data $\left.\mid \beta_{j}\right) * \prod_{j=0}^{J} \frac{1}{\sqrt{2 \pi}} \frac{1}{\delta_{j}} \exp \left\{-\frac{1}{2}\left(\frac{\beta_{j}-\mu_{j}}{\delta_{j}}\right)^{2}\right\}=\sum_{i=1}^{N} \sum_{j=1}^{J} Z_{i j} \ln \operatorname{Prob}\left(y_{i}=j\right) *$ $j=0 / 12 \pi 1 \delta j \exp -12 \beta j-\mu j \delta j 2$.

We incorporated prior information from related research regarding the impact of each variable on WTH to estimate the posterior distribution of model $\beta$ coefficients following [59]. For this study, we set prior means $(\mu)$ based on findings from past studies listed in Table 2 with corresponding normally distributed variances assumed to be 1000 . However, differences in the use of survey methods, model specifications and variable coding in past studies limited our 
ability to capture prior information for all explanatory variables. For variables where prior means were not found, zero was set as its default mean [60].

<Insert Table 2 About Here>

Software Winbugs (the MS Windows Operating System Version of Bayesian Analysis Using Gibbs Sampling) was used for analysis taking random draws from the posterior distribution iteratively. The first 1000 random draws from Gibbs sampling were deleted in order to eliminate initial draw bias $[59,60,61]$. Gibbs sampling ran 10,000 times and results were calculated to estimate model parameters. Deviance Information Criterion (DIC) was used to evaluate the goodness-of-fit of the model. Convergence of Gibbs sampling chain was initially checked from trace plots of the draw chain history and confirmed by checking that the ratio of the Monte Carlo (MC) error and corresponding posterior standard deviation was less than $0.1 \%$ [60]. Statistical significance ( $\alpha=0.05$ ) of $\beta$ coefficients was evaluated by examining results of $97.5 \%$ confidence intervals. If zero was included in the confidence interval, the hypothesis of no significance was failed to be rejected. It is important to note that in the multinomial model a base level category must be selected against which the significance of explanatory variable effects is tested. The integrated harvest was selected as the base level choice in order to more easily evaluate the effect of explanatory variables on NIPF owners' choice of a harvest system that yields timber products and biomass as compared to the other three alternatives.

Parameter odds ratios (OR) were calculated by exponentiating $\beta$ coefficients. This was done to compare the probability differences caused by explanatory variables on NIPF owners' choices 
between the base level (integrated harvest) and other harvest options (timber harvest only, biomass only, and not to harvest), respectively.

NIPF owners' predicted probabilities for the four hypothetical harvest scenarios were estimated based on the results from the reduced model 1 . Equation 5 was used to estimate the probability of the $i$ th landowner of choosing harvesting regime $j$ :

$$
\operatorname{Prob}\left(y_{i}=j\right)=\exp \left(X_{i} \beta_{j}\right) / \sum_{k=1}^{J} \exp \left(X_{i} \beta_{k}\right) \quad \forall k \neq j
$$

where $X_{i}$ is a vector of explanatory variables $(\mathrm{M}, \mathrm{L}, \mathrm{O})$ for landowner $i . \beta_{j}$ is the parameter vector for explanatory variables when landowners select choice $j$, assumed to be independently and identically distributed $[39,40]$. The probability estimates explored market effects including changes in timber and woody biomass revenues on the stated preferences for an average respondent. Specifically, harvesting probabilities were predicted when timber price increased while woody biomass price stayed constant at $\$ 74.13 / \mathrm{ha}$ ( $\$ 30 /$ acre), and when woody biomass price increased while keeping timber price constant at $\$ 1247.88 / \mathrm{ha}$ (\$505/acre), respectively. These levels of product revenues corresponded to the average levels included in the survey.

To further compare the impacts of changes in revenues for timber and woody biomass on NIPF owners' harvesting choices, arc elasticities were estimated. Arc elasticities capture the degree of responsiveness in $\mathrm{WTH}$ as a result of revenue changes. $\mathrm{WTH}_{j}$ elasticity reflects how sensitive a harvesting choice $j$ is to revenue changes (the higher the elasticity, the more sensitive $\mathrm{WTH}_{j}$ is to revenue changes). For instance, in practical terms a higher elasticity of conducting an integrated 
harvesting in response to changes in timber revenues, as compared to woody biomass, indicates that landowners' choices toward integrated harvesting are more sensitive to a change in timber price than woody biomass. $\mathrm{WTH}_{j}$ arc elasticity was calculated as follows:

$$
\mathrm{WTH}_{j} \text { arc elasticity }=\frac{\left(\operatorname{Prob}_{j 2}-\operatorname{Prob}_{j 1}\right) /\left(\frac{\operatorname{Prob}_{j 2}+\operatorname{Prob}_{j 1}}{2}\right)}{\left(\mathrm{P}_{2}-\mathrm{P}_{1}\right) /\left(\frac{\mathrm{P}_{2}+\mathrm{P}_{1}}{2}\right)}
$$

where $\mathrm{P}_{1}$ and $\mathrm{P}_{2}$ represent different timber and/or woody biomass revenue levels. Prob ${ }_{1}$ and $\mathrm{Prob}_{2}$ are the corresponding WTH probabilities of choosing one of the four $J$ options at $\mathrm{P}_{1}$ and $\mathrm{P}_{2}$, respectively.

\section{Results and Discussion}

\subsection{Descriptive statistics}

Adjusted response rates after removing undeliverable surveys were 31\% in Michigan, $45 \%$ in Minnesota and 32\% in Wisconsin, respectively, which are comparable with previous NIPF owners' studies [35, 45]. In response to all harvesting scenarios, around 38\% of the responses indicated their willingness to conduct integrated commercial timber and woody biomass harvesting, $8 \%$ preferred traditional commercial timber harvesting only, 52\% were not willing to harvest at all, and only $2 \%$ of the landowners indicated WTH woody biomass without commercial timber harvesting. Approximately, $31 \%$ of the respondents owned at least 40.47 ha (100 acres) of forest land. In terms of respondents' ownership motivations, enjoying beauty and scenery was the most important reason included in the survey, which is consistent with national trends [3]. Descriptive statistics are provided in Table 3. 


\subsection{Factors affecting NIPF owners' WTH}

5.2.1. Market characteristics: revenues from timber and woody biomass

Results from the reduced and full multinomial logit regression models indicated that revenues associated to timber and woody biomass prices were statistically influential factors on stated NIPF owners' WTH choices and their magnitude was remarkably similar (Table 4). However, there was one exception. There was a non-significant effect of commercial timber revenues on preferences between conducting integrated harvesting or traditional harvesting. This may suggest that once landowners agreed to harvest timber, timber prices would not significantly affect woody biomass harvesting preferences. The non-significant effect of the $\beta$ coefficient capturing timber revenue effects on stated WTH choices between an integrated or traditional harvest was confirmed by the fact that the value of 'zero' was found in its corresponding $97.5 \%$ confidence interval $(-0.000466,0.001612)$. This insignificant effect stresses the point that timber prices did not significantly influence NIPF owners' choice between integrated or traditional harvesting.

Compared to timber, woody biomass revenue had a consistent effect between these two harvest choices. When woody biomass revenue increased by $\$ 2.47 /$ ha $(\$ 1 / \mathrm{ac})$, the average NIPF owner was $1 \%$ more likely to choose an integrated harvest over a traditional commercial harvest where only commercial timber products were removed.

When comparing landowners' WTH between conducting integrated harvesting or not harvesting their forestlands, a one dollar change in woody biomass revenue per acre (OR: 0.9964) had 
nearly the same effect as one dollar change in timber revenues (OR: 0.9965). In other words, when holding other variables constant a dollar increase in timber or woody biomass revenues made a forest owner who initially indicated no willingness to harvest at all to be $1 \%$ more likely to choose an integrated harvest. Timber and woody biomass revenues had similar and statistically significant effects on the choice of an integrated harvest over an option of harvesting woody biomass but not timber products. We expand on the impacts of price conditions in Section 5.3 when we explore expected WTH probabilities.

\author{
<Insert Table 4 About Here>
}

\title{
5.2.2 Land characteristics
}

Impacts of land characteristics were examined in the full model. Acres of forestland owned were statistically significant in influencing NIPF owners' WTH preferences toward conducting a traditional harvest or not willing to harvest at all, in comparison to an integrated harvest. The OR ratio for the forestland acres coefficient suggests that landowners owning more than 40.47 ha (100 ac) of forestland were $32.35 \%$ more likely to choose a traditional harvest rather than an integrated harvest. This finding is consistent with other studies $[62,63]$ that argue that owners of larger land holdings have greater financial incentives to manage their forest intensively and, thus, behave differently from owners with smaller forest parcels. Specific to preferences among larger ownerships to harvest only timber over an integrated harvest, it has been argued that timber

products tend to dominate owner's management decisions as forestry properties grow larger [14]. It is also noticeable by the negative and statistically significant OR (denoting $24.73 \%$ lower 
preferences for not harvesting products at all compared with an integrated harvest), that larger ownerships captured a greater probability to harvest timber and woody biomass.

Commercial timber volume in the county where the forestlands were located had a statistically significant influence in favor of a NIPF owner choosing an integrated harvest over not willing to harvest. We argue that as timber volume captures the availability of quality timber, better timber quality extends to greater willingness to manage and harvest forestlands. Similar to the lack of significance of timber price between a commercial timber harvest and an integrated harvest noted earlier, we argue that once an owner chooses to harvest timber -which already reflects timber quality - there is no major effect of this variable on a choice for integrated harvest versus timber only.

\subsubsection{Landowner characteristics}

Absentee ownership resulted in a higher probability of conducting an integrated harvest over harvesting woody biomass only and not willing to harvest at all. The finding that absentee landowners were more likely to harvest their forestlands is inconsistent with Conway [28], who found that in the state of Virginia absentee landowners were less likely to harvest their forestlands compared with resident owners. Our finding may be linked to whether a forest owner has developed a management plan. In our sample, 50\% of absentee landowners had a forest management plan written by a professional forester compared with $35 \%$ of resident owners. We argue that having a professionally written management plan makes NIPF owners more likely to conduct an integrated harvest over no harvesting or harvesting woody biomass only. Our results 
also showed that no differences existed between onsite and absentee landowners regarding choice for integrated or traditional timber harvesting.

Results from the full model also show that variables capturing attitudes toward woody biomass harvesting, potential impacts on soil erosion, and income levels significantly influenced landowners' choice of conducting an integrated harvest compared with traditional harvesting [30, $32,33]$. For instance, landowners who agreed that woody biomass harvesting is likely to result in soil erosion indicated a higher probability of conducting traditional harvesting over an integrated harvest. To the contrary, landowners who supported harvesting woody biomass for bioenergy were more likely to choose an integrated harvest. Also, landowners with higher annual household income levels were more likely to harvest both commercial timber and woody biomass compared with harvesting commercial timber only. This finding is similar to those of Aguilar et al. [12] that found that individuals of higher income levels were more sensitive to revenues, which could be increased by the additional removal of woody biomass.

Variables representing landowner characteristics except for 'Income' and 'Sawlog Production', were statistically significant when comparing landowners' stated choices between not willing to harvest or selecting an integrated harvest. Landowners, who have sold timber in the past were more likely to choose an integrated harvest rather than not harvesting at all $[12,13]$. The variable 'Soil erosion' positively influenced landowners' preferences toward harvesting no products compared with an integrated harvest. Respondents for whom it is important to own forests to enjoy beauty or scenery or as a part of their inheritance were less likely to choose an integrated harvest. Results also indicated that NIPF owners who were at least 55 years old were less likely 
to harvest their forestlands for commercial timber and woody biomass, while higher education levels led to a higher probability of choosing harvesting both commercial timber and woody biomass, which is consistent with past findings $[12,35]$.

Our results indicated that NIPF owners who own their forestlands for amenity reasons (e.g. beauty and scenery) were less likely to choose an integrated harvest over not harvesting all or harvesting biomass only. This finding might be explained by the visual appeal of forests with less coarse woody debri, thus, the stronger preference for harvesting woody biomass only among owners in this category. Among owners mainly interested in non-extractive objectives, not harvesting is a dominant management option. We also found that the ownership objective of enjoying scenery did not influence landowners' preferences between integrated harvesting or traditional harvesting - i.e. this ownership objective did not influence woody biomass harvesting choices once they agreed to harvest commercial timber [13, 14].

\subsection{Predicted NIPF owners' WTH probabilities}

Estimated WTH probabilities for selected management options under different revenue scenarios were estimated based on results from the reduced model. Figure 1 shows predicted cumulative probabilities of harvesting choices under increasing woody biomass revenues holding revenues from timber sales constant. From top to bottom, shaded areas represent the option of harvesting woody biomass only, no harvest, traditional harvest and integrated harvest. Vertical differences capture the estimated probability of conducting the corresponding harvest option at a given revenue level. The sum of the probabilities for the four included harvest options adds up to $100 \%$. 
The dashed area represents predicted probabilities for woody biomass revenues greater than the maximum level included in the study (\$140/ha).

As shown in Figure 1, an increase in revenues associated with higher woody biomass prices directly affected NIPF owners' probability of choosing an integrated harvest while it decreased the probability of choosing a traditional harvest. When woody biomass price increased from $\$ 20.00 /$ ha (\$8.10/acre) to $\$ 140.00 /$ ha $(\$ 56.68 /$ acre), the probability of the average NIPF owner to choose an integrated harvest increased from around $35.35 \%$ to $40.05 \%$. Revenue changes at this level had an arc elasticity of 0.08 showing a low level of responsiveness (a $1 \%$ change in revenue from woody biomass resulted in a $0.08 \%$ change in the probability of choosing an integrated harvest). Conversely, the probability of choosing a traditional harvest for the average respondent decreased from $9.28 \%$ to $4.34 \%$ with a dollar change increase in revenues per hectare from woody biomass (arc elasticity of -0.48).

<Insert Figure 1 About Here>

WTH probabilities under different timber revenue scenarios are shown in Figure 2. Compared to Figure 1, expected probabilities depicted in Figure 2 show respective harvest choices unvarying timber prices while keeping biomass price constant. The vertical difference between harvest choices indicates the probability of choosing that management option. The dashed area represents predicted probabilities when timber prices are greater than levels included in the study (\$1600/ha). The degree to which an increase in commercial timber price increased NIPF downers' harvesting preferences differed between integrated and commercial timber harvesting only. In 
particular, the probability of harvesting both commercial timber and woody biomass increased to a greater extent than the probability of commercial timber harvesting. When revenues per acre from higher timber revenues increased from $\$ 200.00 /$ ha $(\$ 80.97 /$ acre) to $\$ 1600.00 /$ ha (\$647.77/acre), the probability of harvesting timber and woody biomass increased from 13.33\% to $48.83 \%$ (arc elasticity $=0.74$ ) while the probability of harvesting timber only changed from $1.74 \%$ to $9.27 \%$ (arc elasticity $=0.88$ ). Furthermore, the act elasticity for choosing an integrated harvest as a result of changes in timber revenues (around 0.74 ) was greater than to woody biomass revenue changes (around 0.08) indicating that landowners' choices of conducting integrated harvesting were much more sensitive to changes in timber revenues over biomass. This finding suggests that observed increases in probability of choosing an integrated harvest were mainly associated with higher timber revenues, not woody biomass. It seems that once NIPF owners were satisfied with revenues from the sale of timber they were much more likely to also harvest woody biomass.

$<$ Insert Figure 2 About Here>

Comparing Figures 1 and 2, it can be observed that an increase in woody biomass revenue only had a minimum effect on the probability of choosing an integrated harvest, while it changed sharply when timber price increased. A major decrease in the probability of choosing the no harvest scenario (e.g. from $81.76 \%$ to $41.84 \%$ ) when timber price increased from $\$ 200 /$ ha (\$80.97/acre) to $\$ 1600 /$ ha $(\$ 647.77 /$ acre), is also depicted in Figure 2. However, this trend was not observed when woody biomass price increased and the probability for not harvesting only 
changed from $54.69 \%$ to $52.04 \%$ - when woody biomass price increased from $\$ 20.00 /$ ha (\$8.10/acre) to $\$ 140.00 /$ ha $(\$ 56.68 /$ acre $)$.

Additional predicted probabilities associated with conducting traditional harvest and integrated harvest were calculated and are provided in Appendix C. Probability ratios of conducting integrated harvest over timber harvest (including both integrated and traditional harvest since timber is harvested under both options) are all above $80 \%$. This finding shows that once landowners choose to harvest timber, around $80 \%$ of them are also willing to harvest biomass. It also suggests that NIPF owners are more willing to harvest biomass once they decided to harvest timber compared to no woody biomass harvest (less than 20\%). We further tested whether timber revenue was still an important factor influencing landowners' choice of woody biomass harvest once they are already willing to harvest timber. We grouped ratios based on their timber prices and compared the differences of median ratios medians groups using Kruskal-Wallis tests. Our results showed that medians of the ratios under different price levels were not statistically different suggesting that timber price levels do not affect landowners' WTH woody biomass once they have decided to harvest timber.

The observed lower sensitivity of woody biomass price compared to timber has several important implications. Bioenergy policies, namely monetary incentives, aimed at increasing biomass supply may be more efficient when focusing on improving landowners' WTH timber. For instance, instead of providing tax credit to landowners' for woody biomass production, credits associated with the production of timber may be more efficient in increasing biomass supply. Also, managers in bio-energy industry should not only be aware of the changes in woody 
biomass prices but also timber price change, as our results indicate that timber price changes may be a sign of woody biomass supply change from NIPF landowners.

The probability estimation of NIPF owners' harvesting options was based on their stated choices towards a representative acre of forest in the choice experiment under different levels of timber and woody biomass prices. Our results provide important insights to the social availability of woody biomass supply when generalizing mean findings to the entire study area. Our results indicate that when woody biomass can generate revenues of $\$ 74.10 / \mathrm{ha}$ ( $\$ 30 /$ acre) and commercial timber price $\$ 1247.35 /$ ha ( $\$ 505 /$ acre), NIPF owners' woody biomass harvesting probability was on average $37.82 \%$. The biophysical potential for additional woody biomass production for bioenergy purposes in the three states studied has been estimated as high as 37 million dry tons per year from both public and private lands [15]. Given the fact that NIPFs account for $48 \%$ of the forests in this region [3, 4], we estimated that on average 6.72 million dry tons (37 million dry tons/region $\times 48 \%$ NIPFs/region $\times 37.82 \%$ NIPFs' WTH) of woody biomass might be supplied from NIPF landowners per year under the above stated prices. Furthermore, the highest probabilities of NIPF owners' WTH biomass given our revenue scenarios indicate that feedstock availability from NIPFs in Michigan, Minnesota and Wisconsin might not exceed 8.5 million dry tons per year (biomass price $=\$ 74.1 / \mathrm{ha}[\$ 30 /$ acre $]$ and timber price $=\$ 1600 / \mathrm{ha}$ [\$647.50/acre]).

\section{Conclusions}

This study examined factors that influence NIPF owners' stated WTH and estimated probabilities for four harvesting choices: (1) timber products and woody biomass, (2) timber products only, (3) woody biomass only, and (4) not harvesting at selected timber and woody 
biomass price levels. Based on a sample from Michigan, Minnesota and Wisconsin, a Bayesian multinomial logit model elicited the magnitude and significance of market, forestland and landowners' characteristics effects on WTH. Model results were used to estimate WTH probabilities under different revenue scenarios.

On an order of magnitude a dollar increase in revenue from commercial timber or woody biomass harvesting had similar effects on WTH. However, timber prices dominated WTH for an integrated harvest over harvesting woody biomass only and not harvesting at all. NIPF owners were also much more responsive to changes in timber revenues, compared to biomass, as denoted by larger estimated elasticities. In congruence with past studies, landowners' agreement to the statement that woody biomass may result in soil erosion was statistically significant in influencing landowners' harvesting choices. We also found that stated support to the use of woody biomass for bioenergy was a strong predictor to choose an integrated harvest.

Several variables including: revenues from timber, timber volume, absentee residency, ownership amenity motivations, age and education were found to be not influential in affecting integrated harvest preferences among landowners who were willing to harvest timber products. However, these variables were statistically significant in affecting willingness to conduct an integrated harvest over not harvesting at all. Given that woody biomass is removed mainly during an integrated harvest, the aforementioned variables indirectly affected landowners' WTH woody biomass. This finding suggests that factors affecting woody biomass harvesting preferences were mainly conditional on NIPF owners' WTH commercial timber. Any future 
research eliciting WTH woody biomass should take into consideration landowners' commercial timber harvesting preferences and policy factors that may affect these preferences.

Elasticity in stated WTH woody biomass preferences showed that in fact, a percentage increase in timber revenues per acre was more conducive to harvesting woody biomass than revenues for woody biomass. Once NIPF owners were satisfied with revenues from timber sales they would be more willing to have woody biomass removed from their lands, even when prices for woody biomass were relatively low. This finding points to the fact that any public efforts targeting woody biomass revenues will have little effect on their supply from NIPFs and should be discouraged. Instead higher timber prices will have a greater indirect effect on greater supply of woody biomass from NIPFs with the primary mode of procurement being integrated harvests. Supply of woody biomass from NIPFs will increase when timber prices rise. Our findings underscore that the availability of these feedstocks will remain well below those based purely on biophysical features given the central importance of economic and social variables in affecting NIPF harvesting choices.

\section{Acknowledgments:}

This research was funded by the US Department of Agriculture/US Department of Energy Biomass Research and Development Initiative (\#2009-10006-05948) and the US National Institute for Food and Agriculture project number MO-NRSL0893. This publication is not intended to reflect the opinions of these organizations. The authors acknowledge assistance from Mrs. Lana Narine during survey development and data collection stages of this research. 


\begin{abstract}
APPENDIX A $^{1}$
Calculation of commercial timber, pulpwood and biomass volumes for a representative acre of forest in the choice experiment
\end{abstract}

1. Data retrieved from USDA Forest Service FIA.

- Area of timberland in acres

- Net volume of growing-stock on timberland in cubic feet $\left(\mathrm{ft}^{3}\right)$

- All live top and limb biomass on timberland in oven-dry short tons (ODT)

- All live stump (ground to 12 inches or $30.48 \mathrm{~cm}$ ) biomass on timberland in ODT

- All live tree and sapling aboveground biomass on timberland in ODT by forest type and diameter distribution

2. Percentage of commercial timber and woody biomass that could be harvested from the forests in order to protect the harvest sites from degradation.

- State level average commercial timber removal rate (obtained from the Department of Natural Resources in each state):

Michigan: 30\%; Minnesota: 80\%; Wisconsin: 33\%

- State level woody biomass minimum retention level (obtained from Minnesota and Michigan Biomass Harvesting Guidance, the level in Wisconsin was set based on the minimum retention level in Minnesota and Michigan).

Michigan: 33.33\%; Minnesota: 33.33\%; Wisconsin: 33.33\%

\footnotetext{
${ }^{1}$ Original calculations conducted in English system units due to their dominant use by NIPF owners and wood product markets in the U.S. For clarification conversions to the metric system are provided in parentheses.
} 
3. Calculation of volume of commercial timber per acre and amount of woody biomass per acre for each state by using data retrieved from FIA [45].

- Volume of commercial timber per acre, in cords $(\mathrm{cds})=($ Net volume of growing stock trees in cubic feet $\left(\mathrm{ft}^{3}\right)$ on timberland/79.2)/ Area of timberland in acres $\left(1\right.$ cord $\left.=79.2 \mathrm{ft}^{3}\right)$

- Volume of commercial timber per acre that can be harvested (i.e. the volume of commercial timber that can be harvested from representative acre used in the survey) in cds

Michigan: $26 \mathrm{cds} /$ acre $\times 0.3($ average removal rate $)=8 \mathrm{cds} /$ acre $\left(71.73 \mathrm{~m}^{3} / \mathrm{ha}\right)$ Minnesota: $20 \mathrm{cds} /$ acre $\times 0.8($ average removal rate $)=16 \mathrm{cds} / \mathrm{acre}\left(143.46 \mathrm{~m}^{3} / \mathrm{ha}\right)$ Wisconsin: $25 \mathrm{cds} /$ acre $\times 0.33($ average removal rate $)=8 \mathrm{cds} /$ acre $\left(71.73 \mathrm{~m}^{3} / \mathrm{ha}\right)$

- Volume of woody biomass in green tons (gt) per acre $=(($ All live top and limb biomass of growing stock trees in ODT + All live tree and sapling aboveground biomass of rough and rotten cull trees ODT - All live stump of rough and rotten cull trees ODT/Area of timberland in acres) $\times 2$

- Volume of woody biomass in gt per acre that can be harvested (i.e. the volume of woody biomass that can be harvested from representative acre used in the survey) Michigan: $27 \mathrm{gt} / \mathrm{acre} \times 0.66(1-$ minimum retention level $)=18 \mathrm{gt} / \mathrm{acre}(44.46 \mathrm{gt} / \mathrm{ha})$ Minnesota: 30gt/acre $\times 0.66(1-$ minimum retention level $)=20 \mathrm{gt} /$ acre $(49.40 \mathrm{gt} / \mathrm{ha})$ Wisconsin: $29 \mathrm{gt} / \mathrm{acre} \times 0.66(1$-minimum retention level $)=19 \mathrm{gt} / \mathrm{acre}(46.93 \mathrm{gt} / \mathrm{ha})$ 


\section{APPENDIX B}

\section{Average price of commercial timber (sawtimber and pulpwood) per acre}

1. Sawtimber and pulpwood prices calculated using weighted averages of stand composition (FIA data) and timber price by species, obtained from Timber Mart North for each state in dollars per thousand board feet $(\$ / \mathrm{MBF})$

Michigan: Sawtimber: \$150.54/acre (\$371.83/ha); Pulpwood: \$25.06/acre (\$61.90/ha)

Minnesota: Sawtimber: \$74.08/acre (\$182.98/ha); Pulpwood: \$18.01/acre (\$44.48/ha)

Wisconsin: Sawtimber: \$170.67/acre (\$421.55/ha); Pulpwood: \$33.12/acre (\$81.81/ha)

2. The volume of sawtimber per acre for each state in thousand board feet $(\mathrm{MBF} / \mathrm{acre})=(\mathrm{Net}$ volume of sawtimber trees in board feet (bdft) on timberland/Area of timberland in acres)/1000

Michigan: 7.16 MBF/acre (41.74 $\left.\mathrm{m}^{3} / \mathrm{ha}\right)$; Minnesota: 5.54 MBF/acre (32.29 $\left.\mathrm{m}^{3} / \mathrm{ha}\right)$;

Wisconsin: $7.77 \mathrm{MBF} / \mathrm{acre}\left(45.29 \mathrm{~m}^{3} / \mathrm{ha}\right)$

3. Pulpwood $(\mathrm{cds} / \mathrm{acre})=\left(\left(\right.\right.$ Net volume of growing stock trees in $\mathrm{ft}^{3}$, on timberland $)-\mathrm{Net}$ volume of sawlog portion of sawtimber trees in $\mathrm{ft}^{3}$, on timberland)/ Area of timberland in acres $) / 79.2$

Michigan: $11.12 \mathrm{cds} /$ acre $\left(100.42 \mathrm{~m}^{3} / \mathrm{ha}\right)$; Minnesota: $8.32 \mathrm{cds} /$ acre $\left(74.60 \mathrm{~m}^{3} / \mathrm{ha}\right)$;

Wisconsin: $9.67 \mathrm{cds} / \mathrm{acre}\left(86.70 \mathrm{~m}^{3} / \mathrm{ha}\right)$

4. Total average stand value for commercial timber per acre 
Total stand value $=$ Weighted average price for sawtimber $\times$ Volume of sawtimber + Weighted average price for pulpwood $\times$ Volume of pulpwood Michigan: \$1356.08/acre (\$3349.52/ha); Minnesota: \$560.21/acre (\$1383.72/ha); Wisconsin: \$1646.42/acre (\$4066.66/ha)

5. Commercial timber prices per acre $=($ Total average stand value for commercial timber per acre / Volume of commercial timber per acre) $\times$ Volume of commercial timber per acre that can be harvested

Michigan: \$406.82/acre (\$1004.85/ha); Minnesota: \$448.17/acre (\$1106.98/ha);

Wisconsin: \$536.42/acre (\$1324.96/ha)

The average commercial timber prices applied in the survey were rounded to the tens for every state. 


\section{APPENDIX C}

Estimated NIPF owners' WTH probabilities and ratios between traditional and integrated harvests with probability ratios at selected timber and woody biomass revenue levels.

\begin{tabular}{|c|c|c|c|c|c|}
\hline \multirow{2}{*}{$\begin{array}{l}\text { Timber revenue } \\
\text { Woody biomass revenue }\end{array}$} & \multicolumn{5}{|c|}{$\$ 800 /$ ha $(\$ 323 / a c)$} \\
\hline & $\begin{array}{r}\$ 40 / \mathrm{ha} \\
(\$ 16 / \mathrm{ac})\end{array}$ & $\begin{array}{r}\$ 60 / \mathrm{ha} \\
(\$ 24 / \mathrm{ac})\end{array}$ & $\begin{array}{r}\$ 80 / \mathrm{ha} \\
(\$ 32 / \mathrm{ac})\end{array}$ & $\begin{array}{l}\$ 100 / \mathrm{ha} \\
(\$ 40 / \mathrm{ac})\end{array}$ & $\begin{array}{l}\$ 120 / \mathrm{ha} \\
\text { (\$49/ac) }\end{array}$ \\
\hline Prob(traditional) & $4.90 \%$ & $4.33 \%$ & $3.81 \%$ & $3.35 \%$ & $2.94 \%$ \\
\hline Prob(integrated) & $24.38 \%$ & $24.95 \%$ & $25.48 \%$ & $25.95 \%$ & $26.35 \%$ \\
\hline Probability ratio & $83.26 \%$ & $85.22 \%$ & $86.98 \%$ & $88.57 \%$ & $89.98 \%$ \\
\hline Timber revenue & \multicolumn{5}{|c|}{$\$ 1000 /$ ha $(\$ 405 / a c)$} \\
\hline Woody biomass revenue & $\begin{array}{r}\$ 40 / \mathrm{ha} \\
(\$ 16 / \mathrm{ac})\end{array}$ & $\begin{array}{r}\$ 60 / \mathrm{ha} \\
(\$ 24 / \mathrm{ac})\end{array}$ & $\begin{array}{r}\$ 80 / \mathrm{ha} \\
(\$ 32 / \mathrm{ac})\end{array}$ & $\begin{array}{l}\$ 100 / \mathrm{ha} \\
(\$ 40 / \mathrm{ac})\end{array}$ & $\begin{array}{l}\$ 120 / \mathrm{ha} \\
(\$ 49 / \mathrm{ac})\end{array}$ \\
\hline Prob(traditional) & $6.29 \%$ & $5.56 \%$ & $4.90 \%$ & $4.31 \%$ & $3.78 \%$ \\
\hline Prob(integrated) & $29.63 \%$ & $30.34 \%$ & $31.00 \%$ & $31.59 \%$ & $32.11 \%$ \\
\hline Probability ratio & $82.49 \%$ & $84.52 \%$ & $86.35 \%$ & $88.00 \%$ & $89.48 \%$ \\
\hline Timber revenue & \multicolumn{5}{|c|}{$\$ 1200 /$ ha $(\$ 486 /$ ac $)$} \\
\hline Woody biomass revenue & $\begin{array}{r}\$ 40 / \mathrm{ha} \\
(\$ 16 / \mathrm{ac})\end{array}$ & $\begin{array}{r}\$ 60 / \mathrm{ha} \\
(\$ 24 / \mathrm{ac})\end{array}$ & $\begin{array}{r}\$ 80 / \mathrm{ha} \\
(\$ 32 / \mathrm{ac})\end{array}$ & $\begin{array}{l}\$ 100 / \mathrm{ha} \\
(\$ 40 / \mathrm{ac})\end{array}$ & $\begin{array}{l}\$ 120 / \mathrm{ha} \\
(\$ 49 / \mathrm{ac})\end{array}$ \\
\hline Prob(traditional) & $6.25 \%$ & $5.52 \%$ & $4.87 \%$ & $4.28 \%$ & $3.75 \%$ \\
\hline Prob(integrated) & $29.49 \%$ & $30.20 \%$ & $30.86 \%$ & $31.45 \%$ & $31.97 \%$ \\
\hline Probability ratio & $82.51 \%$ & $84.54 \%$ & $86.37 \%$ & $88.02 \%$ & $89.49 \%$ \\
\hline Timber revenue & \multicolumn{5}{|c|}{$\$ 1400 /$ ha $(\$ 567 /$ ac $)$} \\
\hline Woody biomass revenue & $\begin{array}{r}\$ 40 / \mathrm{ha} \\
(\$ 16 / \mathrm{ac})\end{array}$ & $\begin{array}{r}\$ 60 / \mathrm{ha} \\
(\$ 24 / \mathrm{ac})\end{array}$ & $\begin{array}{r}\$ 80 / \mathrm{ha} \\
(\$ 32 / \mathrm{ac})\end{array}$ & $\begin{array}{l}\$ 100 / \mathrm{ha} \\
(\$ 40 / \mathrm{ac})\end{array}$ & $\begin{array}{l}\$ 120 / \mathrm{ha} \\
\text { (\$49/ac) }\end{array}$ \\
\hline Prob(traditional) & $9.57 \%$ & $8.47 \%$ & $7.47 \%$ & $6.58 \%$ & $5.78 \%$ \\
\hline Prob(integrated) & $40.58 \%$ & $41.62 \%$ & $42.58 \%$ & $43.46 \%$ & $44.24 \%$ \\
\hline Probability ratio & $80.92 \%$ & $83.10 \%$ & $85.07 \%$ & $86.85 \%$ & $88.45 \%$ \\
\hline Timber revenue & \multicolumn{5}{|c|}{$\$ 1600 / \mathrm{ha}(\$ 648 / \mathrm{ac})$} \\
\hline Woody biomass revenue & $\begin{array}{r}\$ 40 / \mathrm{ha} \\
(\$ 16 / \mathrm{ac})\end{array}$ & $\begin{array}{r}\$ 60 / \mathrm{ha} \\
(\$ 24 / \mathrm{ac})\end{array}$ & $\begin{array}{r}\$ 80 / \mathrm{ha} \\
(\$ 32 / \mathrm{ac})\end{array}$ & $\begin{array}{l}\$ 100 / \mathrm{ha} \\
(\$ 40 / \mathrm{ac})\end{array}$ & $\begin{array}{l}\$ 120 / \mathrm{ha} \\
(\$ 49 / \mathrm{ac})\end{array}$ \\
\hline Prob(traditional) & $11.45 \%$ & $10.14 \%$ & $8.96 \%$ & $7.90 \%$ & $6.94 \%$ \\
\hline Prob(integrated) & $46.05 \%$ & $47.28 \%$ & $48.42 \%$ & $49.45 \%$ & $50.38 \%$ \\
\hline Probability ratio & $80.08 \%$ & $82.34 \%$ & $84.38 \%$ & $86.23 \%$ & $87.89 \%$ \\
\hline
\end{tabular}




\section{References}

[1] Smith WB, Miles PD, Perry CH, Pugh SA. Forest resources of the United States, 2007.

Gen. Tech. Rep. WO-78. 2009. U.S. Department of Agriculture, Forest Service, Washington.

[2] Alvarez M. The state of America's forests. Bethesda, MD: Society of American Foresters. DIANE Publishing; 2007.

[3] Butler BJ. Family forest owners of the United States, 2006. Gen. Tech. Rep. NRS-27. 2008. Newtown Square, PA: US Department of Agriculture, Forest Service, Northern Research Station.

[4] Shifley SR, Aguilar FX, Song N, Stewart SI, Nowak DJ, Gormanson DD, et al. Forests of the Northern United States. Gen. Tech. Rep. NRS-90. 2012. Newtown Square, PA: U.S. Department of Agriculture, Forest Service, Northern Research Station.

[5] Aguilar FX, Saunders A. Policy instruments promoting wood for energy uses: evidence from the continental U.S. J Forest 2010; 108(3):132-40.

[6] Aguilar FX, Song N, Shifley S. Review of consumption trends and public policies promoting woody biomass as an energy feedstock in the U.S. Biomass Bioenerg 2011; 35: 370818.

[7] U.S. Forest Service [Internet]. Woody biomass utilization. 2008 [cited 2012 Aug 10]. Available from: http://www.fs.fed.us/woodybiomass/whatis.shtml.

[8] U.S. Department of Energy. U.S. Billion-ton update: biomass supply for a bioenergy and bioproducts industry. R.D. Perlack and B.J. Stokes (Leads), ORNL/TM-2011/224. 2011. Oak Ridge National Laboratory, Oak Ridge. 
[9] Energy Information Administration [Internet]. Annual energy outlook 2012 with projections to 2035. 2012 [cited 2013 Mar 10]. Available from: http://www.eia.gov/forecasts/aeo/pdf/0383(2012).pdf.

[10] Woodall CW, Ince PJ, Skog KE, Aguilar FX, Keegan CE, Sorenson CB, Hodges DG, Smith WB. An overview of the forest products sector downturn in the United States. Forest Prod J 2012; 61: 595-603.

[11] Butler BJ, Ma, Z, Kittredge, DB, Catanzaro, P. Social versus biophysical availability of wood in the northern United States. Northern J Appl Forestry 2010; 27(4): 151-159.

[12] Aguilar, FX, Daniel, M, Cai, Z. Family-forest owners' willingness to harvest sawlogs and woody biomass: the effect of price on social availability. Agr Resource Econ Rev 2014; 43(2). Available from: http://ageconsearch.umn.edu/bitstream/172410/2/ARER2014\%2008\%20Aguilar\%20AEPrePubl. pdf

[13] Markowski-Lindsay M, Stevens T, Kittredge DB, Butler BJ, Catanzaro P, Damery D. Family forest owner preferences for biomass harvesting in Massachusetts. Forest Policy Econ 2012; 14 (1): 127-35.

[14] Aguilar, FX, Daniel, M, Narine, LL. Opportunities and challenges to the supply of woody biomass for energy from Missouri nonindustrial privately owned forestlands. J Forest. 2013; 11(4): 249-260.

[15] Becker D, Skog K, Hellman A, Halvorsen K, Mace T. An outlook for sustainable forest bioenergy production in the Lake States. Energ Policy 2009; 37: 5687-93. 
[16] Aguilar FX, Goerndt M, Song N, Shifley S. Internal, external and location factors influencing cofiring of biomass with coal in the U.S. Northern Region. Energ Econ 2012; 34(6): 1790-98.

[17] Binkley C. Timber supply from nonindustrial forests: a microeconomic analysis of landowner behavior. Yale University Press, New Haven; 1981.

[18] Dennis DF. An economic analysis of harvest behavior: integrating forest and ownership characteristics. Forest Sci 1989; 35 (4): 1088-1104.

[19] Amacher G, Koskela E, Ollikainen M, Conway C. Bequests and forest landowners: theory and empirical evidence. Am J Agr Econ 2002; 84 (4): 1103-14.

[20] Conway C, Chapman S, Amacher GS, Sulliavan J. Differences in non-industrial landowner behavior between hardwood and pine regions of Virginia: implications for timber supply. SOFAC Report No. 19; 2000.

[21] Kline D, Alig J, Johnson L. Fostering the production of nontimber services among forest owners with heterogeneous objectives. Forest Sci 2000; 46 (2): 302-11.

[22] Koonnathamdee P. Exploring NIPF ownership objective categories, willingness to harvest timber, and interest in non-timber uses [Internet]. 2010 [cited 2013 Jan 10]. Available from: http://sofew.cfr.msstate.edu/papers/koonnathamdee10.pdf.

[23] Young RA, Reichenbach MR. Factors influencing the timber harvest intentions of nonindustrial private forest owners. Forest Sci 1987; 33 (2): 381-93.

[24] Pattanayak SK, Abt KL, Holmes TP. Timber and amenities on nonindustrial private forest land. Forest Sci 2003; 72: 243-58. 
[25] Pattanayak SK, Murray BC, Abt RC. How joint is joint forest production? an econometric analysis of timber supply conditional on endogenous amenity values. Forest Sci 2002; 48 (3): 479-91.

[26] Bolkesjø TF, Baardsen S. Roundwood supply in Norway: micro-level analysis of selfemployed forest owners. Forest Policy Econ 2002; 4 (1): 55-64.

[27] Hyberg BT, Holthausen DM. The behavior of nonindustrial private forest landowners. Can J Forest Res 1989; 19 (8):1014-23.

[28] Conway MC, Amacher GS, Sullivan J, Wear D. Decisions nonindustrial forest landowners make: an empirical examination. J Forest Econ 2003; 9: 181-203.

[29] Zhang Y, Zhang D, Schelhas J. Small-scale non-industrial private forest ownership in the United States: rationale and implications for forest management. Silva Fenn 2005; 39 (3): 443-54.

[30] Joshi S, Arano KG. Determinants of private forest management decisions: a study on West Virginia NIPF landowners. Forest Policy Econ 2009; 11 (2): 118-25.

[31] Vokoun M, Amacher GS, Wear DN. Scale of harvesting by nonindustrial private forest landowners. J Forest Econ 2006; 11 (4): 223-44.

[32] Becker D, Klapperich J, Domke G, Kilgore M, D'Amato A, Current D, Ek A. 2010

Outlook for forest biomass availability in Minnesota: physical, environmental, economic, and social availability. 2010. Department of Forest Resources, College of Food, Agricultural and Natural Resource Sciences, University of Minnesota, St. Paul.

[33] Joshi O, Mehmood SR. Factors affecting nonindustrial private forest landowners' willingness to supply woody biomass for bioenergy. Biomass Bioenerg 2011; 35 (1):186-92. [34] Shivan GC, Kuipers B, Potter-Witter K. Determinants of Michigan's nonindustrial private forest landowners' willingness to supply biomass for bioenergy [Internet]. 2011 [cited 
2013 Jan 12]. Available at:

http://www.michiganforestbiofuels.org/sites/default/files/NIPF\%20Bioenergy\%20Factsheet.pdf.

[35] Gruchy SR., Grebner DL, Munn IA, Joshi O, Hussain A. An assessment of nonindustrial private forest landowner willingness to harvest woody biomass in support of bioenergy production in Mississippi: a contingent rating approach. Forest Policy Econ 2012; 15: 140-5.

[36] Hubbard W, Biles L, Mayfield C, Ashton S. Sustainable forestry for bioenergy and biobased products: trainers curriculum notebook. Athens, GA: Southern Forest Research Partnership, Inc. 316p; 2007.

[37] Saunders AM, Aguilar FX, Dwyer JP, Stelzer HE. Cost structure of integrated harvesting for woody biomass and solid hardwood products in southeastern Missouri. J forest 2012; 110 (1): $7-15$.

[38] Gan J, Smith CT. Availability of logging residues and potential for electricity production and carbon displacement in the USA. Biomass Bioenerg 2006; 20: 1011-20.

[39] Marschak J. Binary-choice constraints and random utility indicators. Proceedings of a Symposium on Mathematical Methods in the Social Sciences; 1960.

[40] Manski CF. The structure of random utility models. Theor decis 1977; 8 (3): 229-54.

[41] Narine L. Woody biomass availability for energy: a perspective from non-industrial private forest landowners in the U.S. Great Lakes States. M.S. Thesis: University of Missouri; 2013.

[42] McFadden D. The choice theory approach to market research. Market Sci, INFORMS, 1986; 5 (4): 275-97.

[43] Mas-Colell A, Whinston M, Green J. Microeconomic Theory. Oxford: Oxford University Press; 1995. 
[44] Dillman DA. Mail and internet surveys: the tailored design method. 2nd ed. Wiley and Sons, Inc, New York. 464p; 2000.

[45] Daniel MJ. Social availability of woody biomass for renewable energy: Missouri nonindustrial private forest landowners' perspective. M.S. Thesis: University of Missouri; 2012. [46] Joshi O, Grebner DL, Hussain A, Grado SC. Landowner knowledge and willingness to supply woody biomass for wood-based bioenergy: sample selection approach. J Forest Econ 2013; 19 (2): 97-109.

[47] Miles PD. Forest inventory EVALIDator web-application version 1.5.1.2 beta [Internet]. 2012 [cited 2012 Nov 14]. Available from: www.fiatools.fs.fed.us/Evalidator4/tmattribute.jsp. [48] Prentiss and Carlisle. Timber Mart North Price Report. Michigan Edition 2011a; 17(1): $7 \mathrm{p}$.

[49] Prentiss and Carlisle. Timber Mart North Price Report. Minnesota Edition 2011b; 17(1): $6 \mathrm{p}$.

[50] Prentiss and Carlisle. Timber Mart North Price Report. Wisconsin Edition 2011c; 17(1): $7 \mathrm{p}$.

[51] Broderick SH, Hadden KP, Heninger B. The next generation's forest: woodland owners' attitudes toward estate planning and land preservation in Connecticut. North J Appl For 1994; 11 (2): 47-52.

[52] Butler BJ, Leatherberry EC. America's family forest owners. J Forest 2004; 102 (7): 4-14.

[53] Butler BJ, Tyrrell M, Feinberg G, VanManen S, Wiseman L, Wallinger S. Understanding and reaching family forest owners: lessons from social marketing research. J Forest 2007; 105 (7): $348-57$. 
[54] Voivontas D, Assimacopoulos D, Koukios EG. Assessment of biomass potential for power production: a GIS based method. Biomass Bioenerg 2001; 20 (2): 101-12.

[55] Jackman, S. Models for unordered outcomes. Polit Sci 2003; 150.

[56] Solgaard HS, Hansen T. A hierarchical Bayes model of choice between supermarket formats. Journal of Retailing and Consumer Services 2003; 10 (3): 169-80.

[57] Lunn DJ, Thomas A, Best N, Spiegelhalter D. WinBUGS -- a Bayesian modeling framework: concepts, structure, and extensibility. Stat Comput 2000; 10, 325-37.

[58] Allenby G, Rossi P. Marketing models of consumer heterogeneity. J Econometrics 1998; 89 (1-2): 57-78.

[59] Allenby, GM, Arora, N, Ginter, JL. Incorporating prior knowledge into the analysis of conjoint studies. Journal of Marketing Research 1995; 152-162.

[60] Ntzoufras, I. Bayesian modeling using WinBUGS. Wiley: New York; 2009.

[61] Spiegelhalter D, Thomas A, Best N, Lunn D. WinBUGS User Manual, Version 1.4. MRC Biostatistics Unit, Cambridge, UK; 2003.

[62] Straka TJ, Wisdom HW, Moak JE. Size of forest holding and investment behavior of nonindustrial private owners. J forest 1984; 82 (8): 495-6.

[63] Song N, Aguilar FX, Butler B. Conservation easements and forest management by family forest owners: a propensity score matching approach with multi-imputations of survey data. Forest Sci 2014; 60 (2): 298-307. 
TABLE 1. Price Levels of Commercial Timber (timber and pulpwood) and Woody Biomass Used in the Survey of Non-industrial Private Forest Owners in Michigan, Minnesota and Wisconsin ${ }^{\mathrm{a}}$.

\begin{tabular}{|c|c|c|c|c|c|}
\hline & & \multicolumn{4}{|c|}{ Prices } \\
\hline \multicolumn{6}{|l|}{ Commercial timber } \\
\hline & Michigan & $\begin{array}{l}\$ 815.45 / \mathrm{ha} \\
(\$ 330 / \mathrm{acre})\end{array}$ & $\begin{array}{l}\$ 1013.13 / \mathrm{ha} \\
\text { (\$410/acre) }\end{array}$ & $\begin{array}{l}\$ 1210.82 / \mathrm{ha} \\
\text { (\$490/acre) }\end{array}$ & $\begin{array}{l}\$ 1408.50 / \mathrm{ha} \\
(\$ 570 / \text { acre })\end{array}$ \\
\hline & Minnesota & $\begin{array}{l}\$ 889.58 / \mathrm{ha} \\
\text { (\$360/acre) }\end{array}$ & $\begin{array}{l}\text { \$1111.97/ha } \\
\text { (\$450/acre) }\end{array}$ & $\begin{array}{l}\text { \$1334.37/ha } \\
\text { (\$540/acre) }\end{array}$ & $\begin{array}{l}\$ 1556.76 / \mathrm{ha} \\
\text { (\$630/acre) }\end{array}$ \\
\hline & Wisconsin & $\begin{array}{l}\text { \$1062.55/ha } \\
\text { (\$430/acre) }\end{array}$ & $\begin{array}{l}\$ 1334.37 / \mathrm{ha} \\
(\$ 540 / \text { acre })\end{array}$ & $\begin{array}{l}\text { \$1606.18/ha } \\
\text { (\$650/acre) }\end{array}$ & $\begin{array}{l}\$ 1655.60 / \text { ha } \\
\text { (\$670/acre) }\end{array}$ \\
\hline \multicolumn{6}{|l|}{ Woody biomass } \\
\hline Michigan, & $\begin{array}{l}\text { Minnesota\& } \\
\text { Wisconsin }\end{array}$ & $\begin{array}{l}\$ 0 / \mathrm{ha} \\
\text { (\$0/acre) }\end{array}$ & $\begin{array}{l}\$ 49.42 / \mathrm{ha} \\
\text { (\$20/acre) }\end{array}$ & $\begin{array}{l}\$ 98.84 / \mathrm{ha} \\
\text { (\$40/acre) }\end{array}$ & $\begin{array}{l}\$ 148.26 / \mathrm{ha} \\
\text { (\$60/acre) }\end{array}$ \\
\hline
\end{tabular}

${ }^{a}$ Prices were presented to study participants in \$/acre as these are the units used in the English System for forest measurements in the U.S. 
TABLE 2. Means Used for the Prior Distribution in the Bayesian Analysis

\begin{tabular}{|c|c|c|c|c|}
\hline & \multicolumn{4}{|c|}{ Commercial Timber and Woody Biomass Harvesting } \\
\hline & \multicolumn{2}{|c|}{ Commercial Timber Harvesting } & \multicolumn{2}{|c|}{ Woody Biomass Harvesting } \\
\hline & Mean & Source & Mean & Source \\
\hline Woody biomass price & N/A & N/A & $\begin{array}{l}0.0380 \\
0.0021\end{array}$ & $\begin{array}{c}\text { Becker et al. (2010); Markowski- } \\
\text { Lindsay et al. (2012) }\end{array}$ \\
\hline Absentee $^{\mathrm{a}}$ & -1.9000 & Conway et al. (2003) & $\begin{array}{l}-0.3600 \\
-0.0760\end{array}$ & $\begin{array}{c}\text { Becker et al. (2010); } \\
\text { Markowski-Lindsay et al. (2012) }\end{array}$ \\
\hline Sold timber in the past & N/A & N/A & 0.2660 & Markowski-Lindsay et al. (2012) \\
\hline Amenity & -0.0600 & Joshi and Arano (2009) & -0.4750 & Becker et al. (2010); \\
\hline Soil erosion & N/A & N/A & -0.6320 & Becker et al. (2010) \\
\hline Inheritance & -0.5800 & Conway et al. (2003) & N/A & N/A \\
\hline Sawlog production ${ }^{\mathrm{a}}$ & -0.6500 & Joshi and Arano (2009) & $\begin{array}{l}-0.3920 \\
-0.6600\end{array}$ & $\begin{array}{c}\text { Becker et al. (2010); } \\
\text { Joshi and Mehmood (2011) }\end{array}$ \\
\hline
\end{tabular}

Note: ${ }^{a}$ represents a mean coefficient when more than one prior value was drawn from the literature. 
TABLE 3. Descriptive Statistics for Variables Used in the Bayesian Multinomial Regression Model Predicting Non-industrial Private

Forest Owners' Willingness-to-harvest.

\begin{tabular}{|c|c|c|c|}
\hline Variables & Variable Description & Mean & $\begin{array}{c}\text { Standard } \\
\text { Deviation }\end{array}$ \\
\hline \multirow{4}{*}{$\begin{array}{l}\text { Dependent variable } \\
\text { (Stated harvesting choices) }\end{array}$} & $1=$ Harvest commercial timber and woody biomass & \multirow{4}{*}{2.18} & \multirow{4}{*}{0.98} \\
\hline & $2=$ Harvest commercial timber only & & \\
\hline & $3=$ Not harvest in their forestlands & & \\
\hline & $4=$ Harvest woody biomass only & & \\
\hline \multicolumn{4}{|l|}{ Independent Variables } \\
\hline Timber price & Timber price offered for commercial products harvest & $\begin{array}{r}\$ 1292.38 / \mathrm{ha} \\
(\$ 523.23 / \text { acre })\end{array}$ & $\begin{array}{r}\$ 304.11 / \mathrm{ha} \\
(\$ 123.12 / \text { acre })\end{array}$ \\
\hline Commercial timber volume & County-level volume of commercial timber (Data retrieved from FIA) & $\begin{array}{r}\$ 73.80 / \mathrm{ha} \\
(\$ 29.88 / \mathrm{acre}) \\
8.88 \times 10^{6} \mathrm{~m}^{3} \\
\left(313.65 \times 10^{6} \mathrm{ft}^{3}\right)\end{array}$ & $\begin{array}{r}\$ 55.28 / \mathrm{ha} \\
(\$ 22.38 / \mathrm{acre}) \\
4.33 \times 10^{6} \mathrm{~m}^{3} \\
\left(152.77 \times 10^{6} \mathrm{ft}^{3}\right)\end{array}$ \\
\hline Forestland acres & $1=$ if number of forestland acres the respondent owns is greater than 100 acres $(40.47 \mathrm{ha}), 0=$ otherwise & 0.37 & 0.48 \\
\hline Absentee owner & $\begin{array}{l}1=\text { if respondent's forestland located on a separate, non-adjoining, parcel of land from his/her home, } \\
0=\text { otherwise }\end{array}$ & 0.72 & 0.45 \\
\hline Sold timber in the past & $1=$ if landowner has sold timber in the past, $0=$ otherwise & 0.57 & 0.49 \\
\hline Soil erosion ${ }^{\mathrm{a}}$ & $\begin{array}{l}1=\text { if respondent (strongly) agrees with the statement "Harvesting woody biomass is likely to result in } \\
\text { soil erosion.", } 0=\text { otherwise }\end{array}$ & 2.94 & 0.94 \\
\hline Support biomass harvesting ${ }^{\mathrm{a}}$ & $\begin{array}{l}1=\text { if respondent (strongly) agrees with statement "I support harvesting woody biomass for energy", } \\
0=\text { otherwise }\end{array}$ & 3.51 & 0.93 \\
\hline Amenity ownership ${ }^{a}$ & $1=$ if "Enjoying beauty or scenery" is important ownership reason, $0=$ otherwise & 3.96 & 0.98 \\
\hline Sawlog production ${ }^{\mathrm{a}}$ & $\begin{array}{l}1=\text { if "Owning the forest lands for production of sawlogs, pulp-wood or other timber products" is } \\
\text { important ownership reason, } 0=\text { otherwise }\end{array}$ & 2.49 & 1.29 \\
\hline Inheritance $^{\mathrm{a}}$ & $1=$ if "Owning the land as part of their inheritance" is important ownership reason, $0=$ otherwise. & 2.56 & 1.47 \\
\hline Income $\dagger$ & $1=$ if respondent annual household income is higher than $\$ 50,000,0=$ otherwise. & 0.70 & 0.45 \\
\hline Age $\dagger$ & $1=$ if respondent is older than $55,0=$ otherwise & 0.69 & 0.46 \\
\hline Education $\dagger$ & $1=$ if respondent has at least a bachelor's degree, $0=$ otherwise. & 0.43 & 0.50 \\
\hline
\end{tabular}


${ }^{\mathrm{a}}$ Means and standard deviations were calculated based on the five-point scale $(1=$ Strongly disagree/Not important; $2=$ Disagree/Slightly important; $3=$ Neither agree nor disagree/Moderately important; 4= Agree/Very important; 5=Strongly agree/Extremely important).

$\dagger$ Original information was captured using the following categories:

Annual household income: < \$25,000, \$25,000 - \$49,999, \$50,000 - \$99,999, \$100,000 - \$199,999, \$200,000 or more

Education: < 12th grade, High school degree or GED, Some college, Associate or technical degree, Bachelor's degree, Graduate degree.

Age: $<25,25$ to 34,35 to 44,45 to 54,55 to 64,65 to 74,75 or older 
TABLE 4. Bayesian Multinomial Regression Results for Models Predicting Non-industrial Private Forest Landowners' Willingness-

to-harvest in Michigan, Minnesota, and Wisconsin.

\begin{tabular}{|c|c|c|c|c|c|c|c|c|c|c|c|c|}
\hline \multicolumn{7}{|c|}{ Reduced Model $\dagger$} & \multicolumn{6}{|c|}{ Full Model $\dagger$} \\
\hline & \multicolumn{2}{|c|}{$\begin{array}{l}\text { WTH commercial } \\
\text { products but not } \\
\text { woody biomass }\end{array}$} & \multicolumn{2}{|c|}{$\begin{array}{l}\text { WTH woody biomass } \\
\text { but not commercial } \\
\text { products }\end{array}$} & \multicolumn{2}{|c|}{$\begin{array}{l}\text { Not willing to harvest } \\
\text { commercial products } \\
\text { and woody biomass }\end{array}$} & \multicolumn{2}{|c|}{$\begin{array}{c}\text { WTH commercial } \\
\text { products but not woody } \\
\text { biomass }\end{array}$} & \multicolumn{2}{|c|}{$\begin{array}{l}\text { WTH woody biomass } \\
\text { but not commercial } \\
\text { products }\end{array}$} & \multicolumn{2}{|c|}{$\begin{array}{l}\text { Not willing to harvest } \\
\text { commercial products } \\
\text { and woody biomass }\end{array}$} \\
\hline & Odds Ratio & $\begin{array}{l}\text { MC } \\
\text { Error }\end{array}$ & Odds Ratio & $\begin{array}{l}\mathrm{MC} \\
\text { Error }\end{array}$ & Odds Ratio & $\begin{array}{l}\mathrm{MC} \\
\text { Error }\end{array}$ & Odds Ratio & $\begin{array}{l}\text { MC } \\
\text { Error }\end{array}$ & Odds Ratio & $\begin{array}{l}\text { MC } \\
\text { Error }\end{array}$ & Odds Ratio & $\begin{array}{l}\text { MC } \\
\text { Error }\end{array}$ \\
\hline Constant & $(-) 0.1785^{* *}$ & 0.0007 & $(-) 0.0353^{* *}$ & 0.0025 & $1.3415^{* *}$ & 0.0004 & $(-) 0.2518^{* *}$ & 0.0116 & $(-) 0.0494 * *$ & 0.0204 & $2.2436^{* *}$ & 0.0062 \\
\hline $\begin{array}{l}\text { Timber price } \\
\text { Woodv biomass }\end{array}$ & 1.0007 & $<0.0001$ & $(-) 0.9958^{* *}$ & $<0.0001$ & $(-) 0.9965 * *$ & $<0.0001$ & 1.0004 & $<0.0001$ & $(-) 0.9953 * *$ & $<0.0001$ & $(-) 0.9957^{* *}$ & $<0.0001$ \\
\hline price & $(-) 0.9819 * *$ & $<0.0001$ & $1.0322 * *$ & $<0.0001$ & $(-) 0.9964 * *$ & $<0.0001$ & $(-) 0.9815 * *$ & $<0.0001$ & $1.0335^{* *}$ & 0.0001 & $(-) 0.9959 * *$ & $<0.0001$ \\
\hline Forestland acres & & & & & & & $1.3235 * *$ & 0.003 & $(-) 0.9122$ & 0.0046 & $(-) 0.7527 * *$ & 0.0015 \\
\hline Timber volume & & & & & & & $(-) 0.9840$ & 0.0006 & $(-) 0.9579$ & 0.0011 & $(-) 0.8967 * *$ & 0.0003 \\
\hline Absentee ownership & & & & & & & $(-) 0.9236$ & 0.0047 & $(-) 0.5238 * *$ & 0.0062 & $(-) 0.6399 * *$ & 0.0025 \\
\hline Sold timber before & & & & & & & $(-) 0.8628$ & 0.0042 & $(-) 0.8658$ & 0.0054 & $(-) 0.6877^{* *}$ & 0.0022 \\
\hline Soil erosion & & & & & & & $2.9008 * *$ & 0.0029 & $(-) 0.6433$ & 0.0048 & $2.3268 * *$ & 0.0017 \\
\hline Amenity ownership & & & & & & & 1.1613 & 0.0045 & $2.3943 * *$ & 0.0099 & $1.5256^{* *}$ & 0.0022 \\
\hline Inheritance & & & & & & & $(-) 0.7574 *$ & 0.002 & $(-) 0.9462$ & 0.0047 & $1.1982 * *$ & 0.0014 \\
\hline Support biomass har & vesting & & & & & & $(-) 0.4080 * *$ & 0.0029 & $(-) 0.6540$ & 0.0066 & $(-) 0.4579 * *$ & 0.0019 \\
\hline Sawlog production & & & & & & & 1.0322 & 0.0023 & $(-) 0.9726$ & 0.0043 & 1.0936 & 0.0013 \\
\hline Income & & & & & & & $(-) 0.6298 * *$ & 0.0024 & 1.1477 & 0.0047 & $(-) 0.8935$ & 0.0015 \\
\hline Age & & & & & & & $(-) 0.8534$ & 0.0034 & $(-) 0.7768$ & 0.0055 & $1.319^{* *}$ & 0.0023 \\
\hline Education & & & & & & & 1.2274 & 0.0031 & $(-) 0.9855$ & 0.0051 & $(-) 0.6931^{* *}$ & 0.0018 \\
\hline Gender & & & & & & & 1.1759 & 0.0032 & 1.2531 & 0.0061 & $1.2523^{*}$ & 0.002 \\
\hline DIC & & & 7693.66 & & & & & & 7046.72 & & & \\
\hline
\end{tabular}




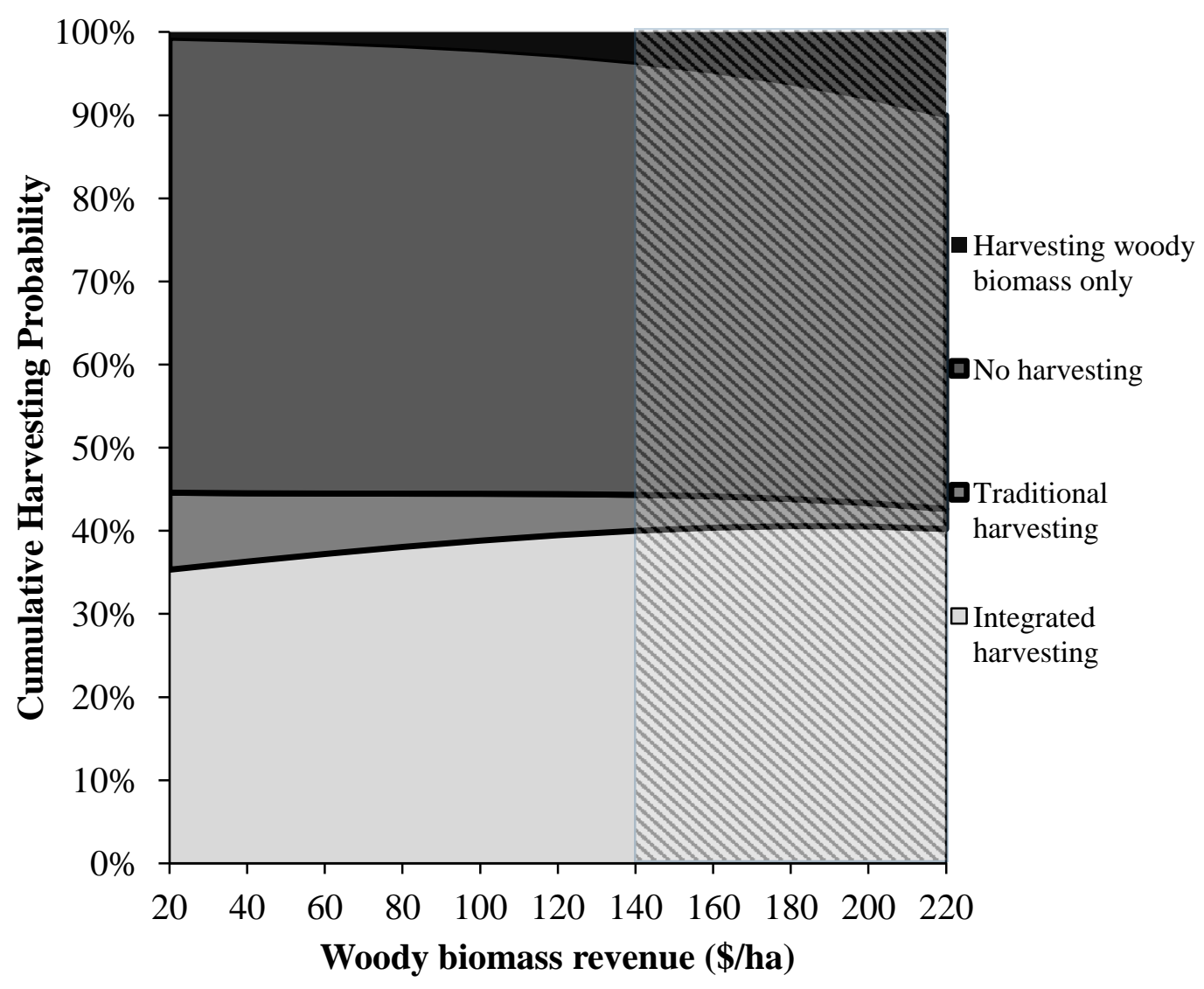

Figure 1. Predicted cumulative probabilities for NIPF owners' WTH under different woody biomass revenues when timber revenues are held constant at $\$ 1247.35 /$ ha. Dashed area represents predicted probabilities for prices greater than market levels elicited in the survey. 


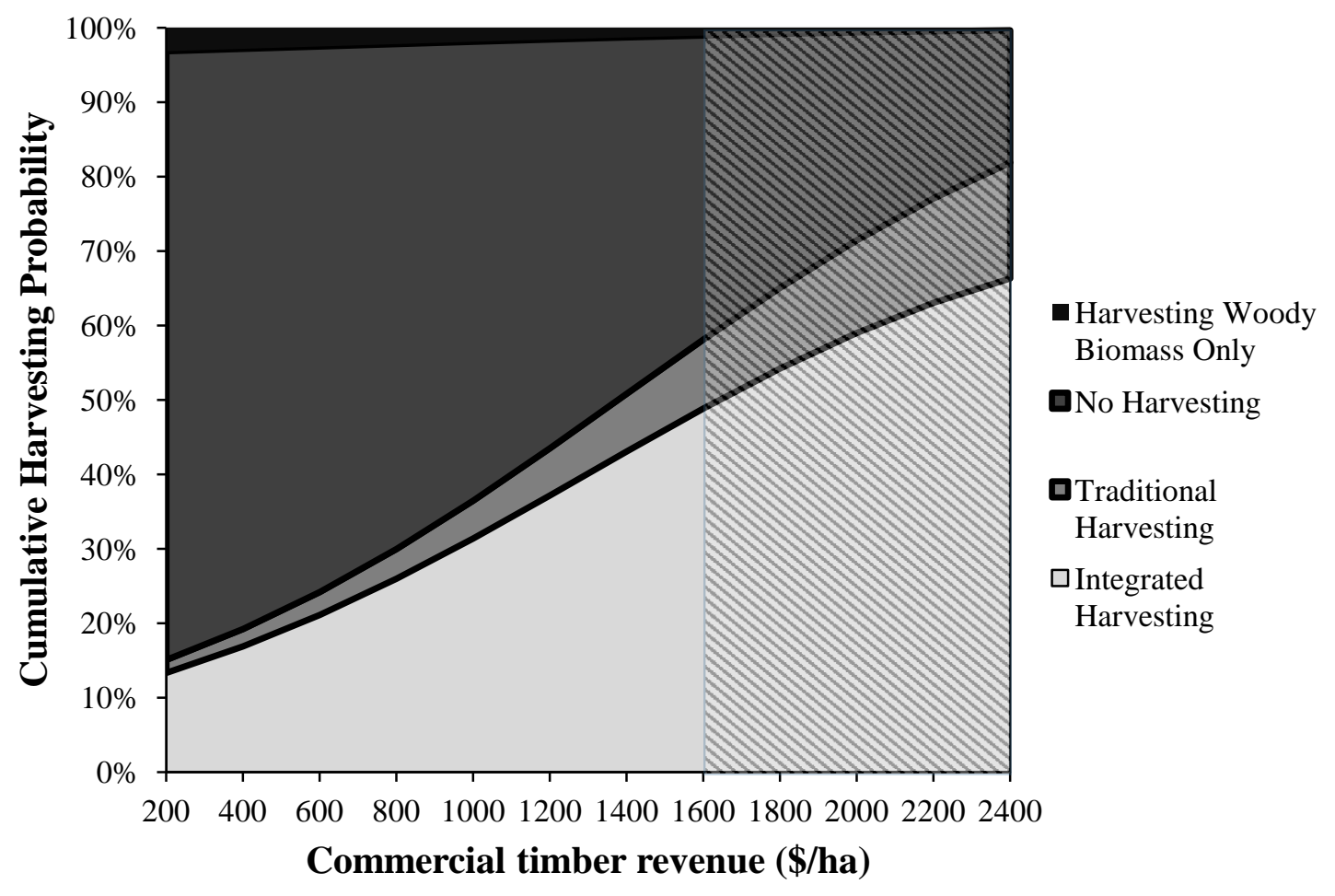

Figure 2. Predicted cumulative probabilities for landowners' willingness-to-harvest under different timber revenues when woody biomass revenues are held constant at \$74.10/ha. Dashed area represents predicted probabilities for prices greater than market levels elicited in the survey. 